\title{
Efektivitas CBIA-Narkoba dalam Peningkatan Pengetahuan Remaja untuk Menolak Narkoba
}

\author{
Effectiveness of CBIA-Drug in Improving Youth Knowledge \\ to Resist Drugs
}

\author{
Sinta Rachmawati ${ }^{*}$, Sri Suryawati ${ }^{2}$, Rustamaji ${ }^{2}$ \\ ${ }^{1}$ Bagian Farmasi Klinik dan Komunitas, Fakultas Farmasi, Universitas Jember, Jember \\ ${ }^{2}$ Pusat Studi Farmakologi Klinik dan Kebijakan, Universitas Gadjah Mada, Yogyakarta \\ ('sinta.rachmawati@unej.ac.id)
}

\begin{abstract}
ABSTRAK
Penyalahgunaan narkoba masih menjadi permasalahan kesehatan yang mendesak di Indonesia. Ceramah menjadi salah satu metode yang paling banyak digunakan untuk memberikan informasi, termasuk bahaya narkoba. CBIA (Cara Belajar Insan Aktif)-Narkoba merupakan metode pendidikan alternatif yang melibatkan diskusi kelompok kecil. Penelitian ini bertujuan menilai efektivitas CBIA-Narkoba dibandingkan dengan metode ceramah dalam peningkatan pengetahuan remaja untuk menolak narkoba. Jenis penelitian yang digunakan adalah eksperimental semu dengan rancangan pre test-post test control group design. Partisipan yang terlibat sebanyak 30 responden untuk kelompok CBIA-Narkoba, 30 responden untuk kelompok intervensi dan 30 responden untuk kelompok kontrol. Analisis statistika multivariat (kruskall wallis) digunakan untuk mengetahui efektivitas antara metode CBIA-Narkoba dengan ceramah. Uji beda post test 1 menunjukkan adanya kebermaknaan antar metode $(\mathrm{p}<0,05)$. Artinya CBIA-Narkoba lebih efektif dalam meningkatkan pengetahuan untuk menolak narkoba dibandingkan metode ceramah.
\end{abstract}

Kata kunci : Efektivitas, CBIA, ceramah, pengetahuan, narkoba

\section{ABSTRACT}

Drug abuse is still a major health problem in Indonesia. The lecture method is one of the most widely used to provide information, including drug. CBIA (Community Based Interactive Approach) drug is an alternative educational method that involves small group discussion. This study aims to assess the effectiveness of CBIA-Drug compared with lecture method in improving youth knowledge to resist drug. Quasi experimental with pre test-post test control group design was used in this study. It involved 30 respondents for CBIA-Drug group, 30 respondents for intervention group and 30 respondents for control group. Mutivariate statistical analysis (kruskall wallis) was used to evaluate the effectiveness of CBIA-Drug. There was a significance value at post test 1 for each group $(p<0.05)$. It means that CBIA-Drug is more effective in improving youth knowledge to resist drug than lecture method.

Keywords : Effectiveness, CBIA, lecture, knowledge, drug 


\section{PENDAHULUAN}

UNODC (United Nation on Drug and Crime) memperkirakan sekitar 255 juta orang (5\% dari populasi orang dewasa berusia 15-64 tahun) menggunakan narkoba setidaknya sekali pada tahun 2015. Angka ini menunjukkan jumlah penyalahguna narkoba di antara populasi dunia tetap stabil selama lima tahun terakhir. Secara global, lebih dari $11 \%$ orang yang menggunakan narkoba (seki$\operatorname{tar} 29,5$ juta orang) diperkirakan menderita permasalahan kesehatan akibat penggunaan narkoba.

Penyalahgunaan narkoba menjadi permasalahan mendesak di Indonesia. Salah satu kelompok yang rentan adalah remaja. ${ }^{2}$ Hasil survei BNN menyebutkan 4 dari 100 orang pelajar/mahasiswa pernah menggunakan narkoba. Setengah dari jumlah tersebut mengonsumsi narkoba dalam rentang setahun terakhir. ${ }^{3}$ Strategi untuk mengatasi permasalahan narkoba dilakukan dengan cara mengurangi penawaran (supply reduction) dan mengurangi permintaan (demand reduction). Upaya untuk mengurangi permintaan dapat dilakukan dengan langkah pencegahan. Program pencegahan yang baik merupakan cara yang efektif biaya (cost effectiveness). Penelitian menunjukkan bahwa setiap 1 dolar yang dihabiskan mampu menghemat pengeluaran pemerintah sampai 10 dolar pada biaya selanjutnya. ${ }^{4}$

Upaya pencegahan sering dilakukan pada masa remaja, ketika kaum muda terpapar ide baru, yaitu pada saat remaja mencoba menjalani peran orang dewasa dan lebih mandiri. Remaja mulai mempunyai keputusan akan keterlibatan dengan perilaku buruk yang berpotensi membahayakan, seperti perilaku seksual berisiko, merokok, minum minuman keras, perilaku mengemudi berisiko dan penggunaan narkoba. Periode perkembangan ini adalah waktu ketika intervensi dapat memperkuat atau mengubah pengalaman sebelumnya. Oleh karena itu, program dengan target usia remaja memberikan hasil yang lebih baik dalam pencegahan penyalahgunaan narkoba daripada program yang menargetkan anak-anak yang lebih muda atau usia yang lebih tua. ${ }^{5}$

Pencegahan yang perlu dilakukan berupa intervensi yang berbasis bukti (evidence based intervention) karena tidak semua intervensi memberikan luaran yang positif. Terdapat beberapa metode peningkatan pengetahuan remaja, dian- taranya dilakukan dengan metode ceramah, testimoni mantan penyalahguna narkoba dan diskusi kelompok kecil. Metode ceramah paling banyak digunakan untuk memberikan informasi, termasuk tentang penyalahgunaan narkoba. Namun, metode ini memiliki kekurangan karena bersifat satu arah. ${ }^{5}$ CBIA (Cara Belajar Insan Aktif)-Narkoba adalah metode pendidikan dengan diskusi kelompok kecil yang interaktif, mendorong partisipasi peserta dan melibatkan fasilitator yang berasal dari kalangan remaja. Fasilitator yang berasal dari kalangan remaja menjadi penting karena tingkat konformitas terhadap teman sebaya adalah salah satu faktor yang berhubungan dengan penyalahgunaan narkoba. ${ }^{6}$ Intervensi CBIA-Narkoba mampu meningkatkan pengetahuan remaja untuk menolak narkoba. ${ }^{7}$ Oleh karena itu, diperlukan penelitian yang bertujuan menilai efektivitas CBIA Narkoba dibandingkan dengan metode ceramah dalam peningkatan pengetahuan remaja untuk menolak narkoba.

\section{BAHAN DAN METODE}

Jenis penelitian yang digunakan adalah eksperimental semu dengan rancangan pre test-post test control group design. Partisipan yang terlibat sebanyak 30 responden untuk kelompok ceramah, 30 responden untuk kelompok CBIA Narkoba dan 30 responden untuk kelompok kontrol. Responden adalah siswa kelas 1 SMAN 1 Bantul Yogyakarta di tiga kelas yang berbeda tahun ajaran 2015/2016, masing-masing sebagai kelompok ceramah, kelompok CBIA-Narkoba dan kelompok kontrol. Kelompok ceramah diisi oleh guru yang menyampaikan materi tentang narkoba sesuai mata pelajaran pendidikan jasmani, olahraga dan kesehatan. Kelompok CBIA-Narkoba dilakukan dengan diskusi kelompok kecil didampingi fasilitator. Terdapat 5 kelompok dengan anggota 6 orang peserta dan 1 orang fasilitator. Fasilitator bertugas memandu jalannya diskusi. Fasilitator adalah siswa yang menjadi kader kesehatan sekolah dan sudah mengikuti pelatihan CBIA Narkoba dalam bentuk Training of Trainer sebelumnya. Buku berjudul "Fakta tentang Narkoba" dibagikan dalam kelompok kecil. Buklet ini terdiri dari dua bagian, 3 orang peserta membaca buku A, sisanya membaca buku B. Kemudian, mereka saling bercerita dan berdiskusi dengan sesama anggota kelompok. Fasilitator memberi penekanan pada 
poin-poin utama sesuai modul CBIA Narkoba untuk fasilitator. Kelompok terakhir, yakni kelompok kontrol tidak mendapat perlakuan.

Kuesioner pengetahuan untuk menolak narkoba adalah instrumen yang dipakai dalam penelitian. Kuesioner sudah diuji validitas dan reliabilitasnya kepada 30 siswa di luar responden penelitian, dan memenuhi syarat. Setiap kelompok mengisi kuesioner pretest sebelum perlakuan. Sesaat setelah perlakuan, kuesioner post test $1 \mathrm{di}$ isi. Kuesioner post test 2 diisi 3 minggu setelah intervensi. Kuesioner pre test 1 , post test 1 dan post test 2 memuat isi pertanyaan yang sama. Analisis statistika multivariat, yaitu uji beda antar metode kruskall wallis, digunakan untuk mengetahui efektivitas antara metode CBIA-Narkoba dengan ceramah. Penyajian data dilakukan dengan tabulasi dan grafik.

\section{HASIL}

Tabel 1 menampilkan karakteristik responden dan informasi narkoba yang dimiliki. Pada masing-masing kelompok, proporsi jenis kelamin perempuan lebih banyak dibanding laki-laki seki- $\operatorname{tar}$ 60\%:40\%. Mayoritas usia responden pada masing-masing kelompok adalah usia 15 tahun. Beberapa responden mengaku pernah mencoba zat adiktif berupa rokok dan minuman beralkohol. Namun, tidak ada satu pun yang menggunakan psikotropika ataupun narkotika. Semua responden $(100 \%)$ pada kelompok CBIA-Narkoba, ceramah dan kontrol pernah mendapatkan informasi tentang narkoba dari berbagai sumber.

Hasil kuesioner pengetahuan untuk menolak narkoba pada kelompok CBIA-Narkoba, ceramah dan kontrol ditampilkan dalam Grafik 1. Terdapat kenaikan skor sesaat setelah perlakuan pada masing-masing kelompok (post test 1). Namun, ada sedikit penurunan 3 minggu setelah perlakuan (post test 2). Tabel 2 menunjukkan rerata skor kuesioner untuk menolak narkoba. Untuk mengetahui efektivitas antara CBIA-Narkoba dan ceramah dalam meningkatkan pengetahuan, maka perlu dilakukan analisis statistika mutivariat yaitu uji beda antar metode dengan kruskall wallis.

Uji beda postest 1 pengetahuan menunjukkan adanya kebermaknaan antar metode. Dari uji lanjutan diketahui antara kelompok CBIA dengan

Tabel 1. Karakteristik Responden dan Informasi Narkoba yang Dimiliki

\begin{tabular}{|c|c|c|c|c|c|c|}
\hline \multirow[b]{2}{*}{ Karakteristik } & \multicolumn{6}{|c|}{ Kelompok } \\
\hline & $\begin{array}{c}\text { CBIA- } \\
\operatorname{Narkoba}(n=30)\end{array}$ & $\%$ & $\begin{array}{c}\text { Ceramah } \\
(n=30)\end{array}$ & $\%$ & $\begin{array}{c}\text { Kontrol } \\
(n=30)\end{array}$ & $\%$ \\
\hline \multicolumn{7}{|l|}{ Jenis kelamin } \\
\hline Laki-laki & 12 & 40 & 12 & 40 & 13 & 43 \\
\hline Perempuan & 18 & 60 & 18 & 60 & 17 & 57 \\
\hline \multicolumn{7}{|l|}{ Usia (tahun) } \\
\hline 14 & 2 & 7 & 1 & 3 & 1 & 3 \\
\hline 15 & 20 & 67 & 23 & 77 & 18 & 60 \\
\hline 16 & 8 & 27 & 6 & 20 & 11 & 37 \\
\hline \multicolumn{7}{|l|}{ Zat adiktif coba pakai } \\
\hline Rokok & 2 & 7 & 1 & 3 & 4 & 13 \\
\hline Minuman Beralkohol & 2 & 7 & 4 & 13 & 0 & 0 \\
\hline Narkotika & 0 & 0 & 0 & 0 & 0 & 0 \\
\hline \multicolumn{7}{|l|}{ Informasi narkoba } \\
\hline Iya & 30 & 100 & 30 & 100 & 30 & 100 \\
\hline Tidak & 0 & 0 & 0 & 0 & 0 & 0 \\
\hline \multicolumn{7}{|l|}{ Sumber informasi* } \\
\hline Media (TV, majalah, koran) & 24 & 80 & 22 & 73 & 24 & 80 \\
\hline Guru & 19 & 63 & 16 & 53 & 19 & 63 \\
\hline Teman & 6 & 20 & 4 & 13 & 5 & 17 \\
\hline Petugas Kesehatan & 21 & 70 & 21 & 70 & 15 & 50 \\
\hline Lainnya & 7 & 23 & 8 & 27 & 8 & 27 \\
\hline
\end{tabular}

* responden bisa mengisi $>1$ 


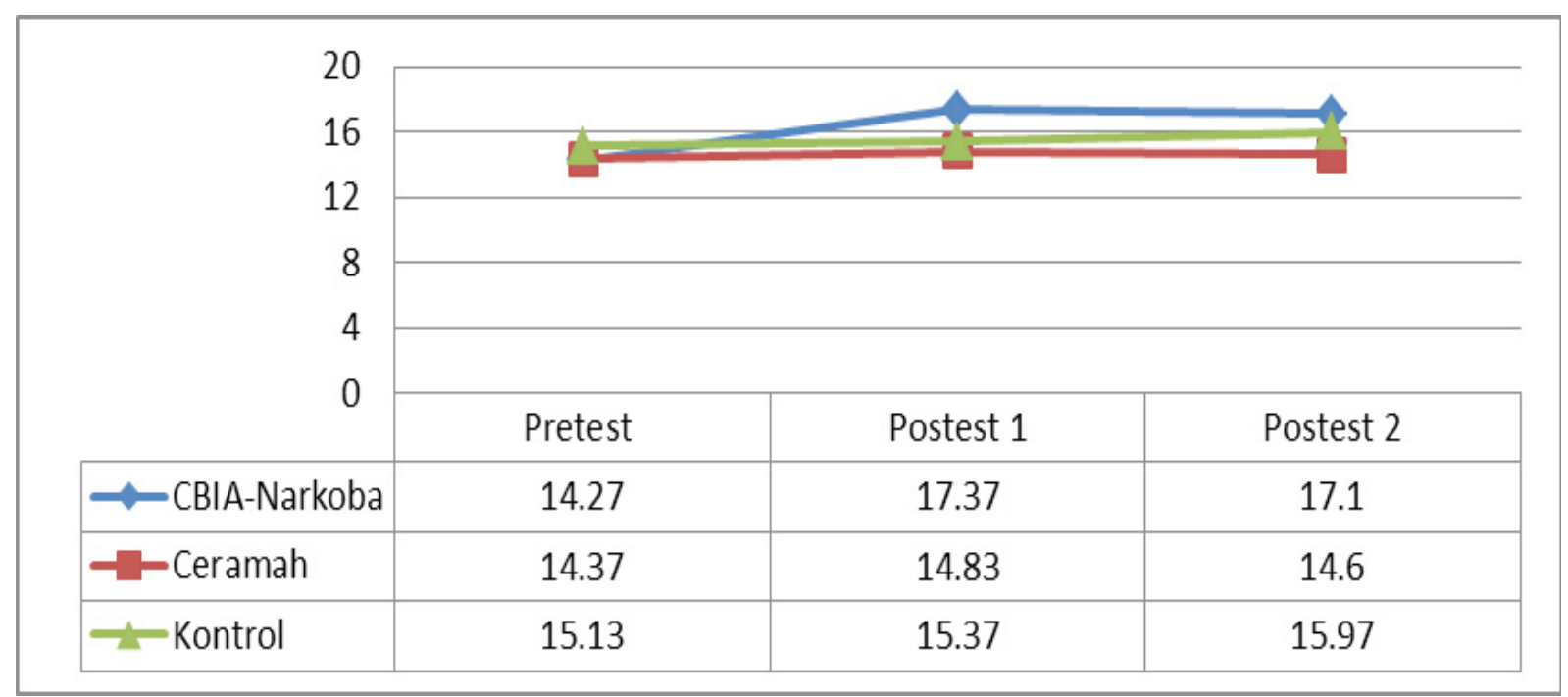

Grafik 1. Skor Rerata Pengetahuan CBIA-Narkoba, Ceramah dan Kontrol

Tabel 2. Rerata Skor Kuesioner Pengetahuan untuk Menolak Narkoba

\begin{tabular}{lccc}
\hline \multicolumn{1}{c}{ Pengetahuan } & Pre test & Post test 1 & Post test 2 \\
\hline Kelompok CBIA-Narkoba $( \pm)$ & 14,27 & $17,37^{*}$ & 17,10 \\
Kelompok Ceramah & 14,37 & $14,83^{*}$ & 14,60 \\
Kelompok Kontrol & 15,13 & 15,37 & 15,97 \\
\hline
\end{tabular}

${ }^{*}$ terdapat perbedaan yang bermakna pada posttest 1 dan posttest 2 pengetahuan dengan kruskall wallis $(\mathrm{p}<0,05)$. Pada uji lanjutan yakni uji beda kelompok CBIA-ceramah dan CBIA-kontrol, terdapat perbedaan yang bermakna $(\mathrm{p}<0,05)$

\pm rentang skor pengetahuan adalah $0-20$

kelompok ceramah dan kontrol masing-masing memberikan hasil yang bermakna yaitu $0,000(\mathrm{p}<$ $0,05)$. Sedangkan post test 1 pengetahuan kelompok ceramah jika dibandingkan dengan kelompok kontrol memberikan hasil tidak bermakna yaitu $0,184(\mathrm{p}>0,05)$. Artinya metode CBIA-Narkoba lebih efektif dalam meningkatkan pengetahuan setelah intervensi dibandingkan metode ceramah.

Uji beda post test 2 pengetahuan menunjukkan adanya kebermaknaan antar metode. Dari uji lanjutan diketahui antara kelompok CBIA dengan kelompok ceramah dan kontrol masing-masing memberikan hasil yang bermakna yaitu 0,000 dan $0,007(\mathrm{p}<0,05)$. Sedangkan post test 2 pengetahuan kelompok ceramah jika dibandingkan dengan kelompok kontrol memberikan hasil yang tidak bermakna yaitu $0,051(\mathrm{p}>0,05)$. Artinya metode CBIA-Narkoba lebih efektif dalam meningkatkan pengetahuan 3 minggu setelah intervensi dibandingkan metode ceramah.

\section{PEMBAHASAN}

Hasil penelitian menunjukkan, semua responden $(100 \%)$ pernah mendapatkan informasi tentang narkoba. Hal ini sejalan dengan penelitian BNN yang menyebutkan bahwa 93\% siswa SMA pernah mendengar berbagai jenis narkoba di tahun 2016. ${ }^{3}$ Meskipun demikian, tidak berarti pengetahuan yang tinggi berkorelasi positif dengan perilaku menolak narkoba. Pemberian informasi yang tidak tepat pada remaja menyebabkan mereka mencoba pakai narkoba.

CBIA-Narkoba dirancang untuk meluruskan mitos yang berkembang di kalangan pemuda tentang narkoba, tidak sekedar memberikan informasi tentang jenis-jenis narkoba dan bahayanya. Pengenalan berbagai substansi narkoba dari sisi wujud dan bentuknya memberikan hasil yang negatif terhadap perilaku menolak narkoba. ${ }^{8} \mathrm{Mi}$ tos yang ingin diluruskan adalah dampak negatif penyalahgunaan narkoba di kalangan remaja lebih 
ringan daripada orang dewasa, narkoba non sintetik lebih aman daripada narkoba sintetik, ada beberapa jenis narkoba yang tidak merugikan bagi remaja serta penggunaan narkoba di usia muda tidak akan menyebabkan ketagihan dan kematian.

Penelitian yang dilakukan oleh Majid menunjukkan bahwa penyuluhan dapat mengubah pengetahuan masyarakat. ${ }^{9}$ CBIA-Narkoba adalah metode penyuluhan yang diadopsi dari metode CBIA. Metode ini mempunyai ciri berbasis pada komunitas, interaktif, melibatkan diskusi kelompok kecil yang dipandu fasilitator. Pada awalnya, metode ini digunakan untuk meningkatkan pengetahuan dan keterampilan ibu dalam pemilihan pengobatan sendiri di rumah tangga. Kemudian, dikembangkan menjadi CBIA-DM, CBIA-diare dan terapi lain dengan hasil yang memuaskan. ${ }^{10-13}$ CBIA-Narkoba adalah hasil modifikasi dari CBIA dengan memasukkan pesan pencegahan penyalahgunaan narkoba.

CBIA-Narkoba diketahui lebih efektif untuk meningkatkan pengetahuan sesaat setelah intervensi dibandingkan metode ceramah. Metode ini juga lebih efektif dalam meningkatkan pengetahuan 3 minggu setelah intervensi dibandingkan metode ceramah. Hal ini sesuai dengan pedoman yang dikeluarkan oleh UNODC tentang pendidikan berbasis sekolah untuk pencegahan penyalahgunaan narkoba. ${ }^{14}$ Pedoman tersebut menyampaikan bahwa intervensi untuk pencegahan penyalahgunaan narkoba menjadi lebih berhasil apabila difokuskan pada siswa dan menggunakan metode interaktif, dengan pembelajaran berdasarkan pengalaman dan diskusi kelompok kecil. Standar internasional tentang pencegahan penyalahgunaan narkoba tahun 2013 juga menyebutkan bahwa intervensi yang interaktif dan dipandu fasilitator memberikan hasil yang positif. Sebaliknya, metode ceramah tidak memberikan dampak atau malah memberikan dampak yang negatif.

Upaya pencegahan penyalahgunaan narkoba sebaiknya tidak berhenti pada aspek pemberian informasi saja. Intervensi yang berkelanjutan dan memberikan ketrampilan sosial dapat memperkuat perilaku penolakan terhadap narkoba. ${ }^{15}$

\section{KESIMPULAN DAN SARAN}

CBIA-Narkoba diketahui lebih efektif untuk meningkatkan pengetahuan untuk menolak narko- ba sesaat setelah intervensi dibandingkan metode ceramah. Efektifitasnya terjaga 3 minggu setelah intervensi. Upaya peningkatan pengetahuan sebaiknya dilanjutkan dengan program terstruktur dalam beberapa sesi yang memberikan keterampilan sosial untuk memperkuat perilaku penolakan terhadap narkoba.

\section{UCAPAN TERIMA KASIH}

Peneliti mengucapkan terima kasih kepada Kepala Sekolah SMAN 1 Bantul yang telah memberikan ijin pengambilan data, seluruh responden yang bersedia mengikuti penelitian dari awal sampai akhir serta BNNP DIY yang telah memberikan dukungan penelitian.

\section{DAFTAR PUSTAKA}

1. UNODC. World Drug Report 2017: Global Overview of Drug Demand and Supply. Vienna: United Nation Office on Drugs and Crime; 2017.

2. BNN RI. Laporan Kinerja Badan Narkotika Nasional Tahun 2016. Jakarta: Badan Narkotika Nasional RI; 2016.

3. BNN RI. Hasil Survei Penyalahgunaan dan Peredaran Gelap Narkoba pada Kelompok Pelajar Mahasiswa di 18 Provinsi Tahun 2016. Jakarta: Badan Narkotika Nasional; 2016.

4. INCB. Report of the International Narcotics Control Boards for 2013. Vienna: International Narcotics Control Boards; 2014.

5. UNODC. International Standards on Drug Use Prevention. Vienna: United Nation Office on Drugs and Crime; 2013

6. M, Asni. Faktor yang Berhubungan dengan Penyalahgunaan Narkoba pada Remaja di SMA Kartika Wirabuana XX-1 Makassar. Jurnal MKMI. 2013;9(3):190-196

7. Rachmawati, S. Upaya Peningkatan Pengetahuan pada Pelajar SMAN 1 Bantul tentang Pencegahan Penyalahgunaan Narkoba dengan Intervensi CBIA-Narkoba. Jurnal Ikesma. 2017;12(1):1-7.

8. UNICEF. Life Skills-Based Education for Drug Use Prevention Training Manual. New York: United Nation Children's Fund; 2001

9. Majid, M. Pengembangan Metode Penyuluhan Meningkatkan Pemakaian Alat Kontrasepsi. 
Jurnal MKMI. 2017;13(1):91-96.

10. Suryawati, S. CBIA: Cara Belajar Ibu Aktif, A Community Based Interactive Approach Toward Safe, Effective and Cost Efficient Self Medication. Yogyakarta: Melati Nusantara Foundation; 2010.

11. Hartayu, T.S, Mi M.I, Suryawati, S. Improving of Type 2 Diabetic Patients' Knowledge, Attitude and Practice Towards Diabetes SelfCare by Implementing Community Based Interactive Approach Diabetes Mellitus Strategy. BMC Res Notes. 2012;5:315.

12. Kumala, AP. CBIA-Diare untuk Meningkatkan Pengetahuan, Sikap dan Perilaku Ibu dalam Tatalaksana Diare pada Balita di Bina Keluarga Balita (BKB) Desa Banguntapan
Kabupaten Bantul. Majalah Farmaseutik. 2016;12(1):390-393

13. Mahardika, AB. Intervensi CBIA untuk Meningkatkan Pengetahuan, Sikap dan Perilaku Penggunaan Antibiotik yang Rasional pada Anggota Bina Keluarga Balita. Jurnal Kedokteran Brawijaya. 2016;29(2):165-169

14. UNODC. School-Based Education for Drug Abuse Prevention. Vienna: United Nation Office on Drugs and Crime; 2004.

15. Griffin, K. W. and Botvin, G. J. Evidence Based Interventions for Preventing Substance Use Disorder in Adolescents. Child Adolesc Psychiatr Clin. 2010;19(3):505-526 